\title{
Dentists' entrepreneurial intention and associated factors in public hospitals in major cities in Guangdong (South China): a cross-sectional study
}

\author{
Jiabi Wang ${ }^{1}$, Bin Peng ${ }^{1}$, Hongzhi Zhou ${ }^{2}$ and Jing Hua Zhang ${ }^{1 *}$ (D)
}

\begin{abstract}
Background: A rapid growth in private dentistry in China has been observed during recent years. Promoting the entrepreneurship of dentists has increasingly received attention in both dentistry and dental education worldwide. However, understanding about the unique features of entrepreneurial behaviors of dentists remains inadequate.

Methods: This study examines dentist's entrepreneurial intention (El), which was represented by his/her intention of leaving the public hospital system to be engaged in the private sector. Through a snowball sampling method, a total of 336 questionnaires from public hospitals in five major cities in Guangdong Province (China) were collected. The association between the dentists' $\mathrm{El}$ and their individual characteristics were analyzed using a logistic regression model.

Results: In the sample studied, $35.7 \%$ of the respondents reported to have El. Female dentists are less likely to report El $(O R=0.365, p=0.001)$. Dentists in the age group of 36 to 45 years $(O R=14.205, p=0.012)$ and those aged over 45 years $(\mathrm{OR}=8.45, p=0.066)$ reported respectively a much stronger $E$ l than those in their 20s. Compared with intern dentists, attending dentists ( $\mathrm{OR}=7.812, p=0.016)$ and associate/chief dentists $(\mathrm{OR}=9.857, p=0.021)$ were significantly more likely to report El. Those with master level $(\mathrm{OR}=0.221, p=0.021)$ or doctorate degrees $(\mathrm{OR}=0.118, p=0.005)$ are much less likely to report El. Meanwhile, those in mid-large hospitals (with 101-200 employees) $(\mathrm{OR}=3.554, p=0.036)$ and small hospitals (with $<50$ employees) $(\mathrm{OR}=2.398, p=0.044)$ reported a stronger El than those in large hospitals. Additionally, dentists' entrepreneurial behaviors, risk aversion attitudes and their family background all have significant associations.

Conclusions: Since dentistry is a knowledge-intensive industry, dentists' entrepreneurial behaviors have their own features. The findings by this study suggest that, accumulation of practical skills in a dental career, as implied by age, professional qualifications and leadership skills, help to promote El, whereas an academic oriented education degree per se does not. Dentists in mid-large and small hospitals, rather than in top large hospitals in China, have higher El. Additionally, female dentists may need more social supports to develop a higher El. These findings have practical implications for the promotion of El among dentists.
\end{abstract}

Keywords: Entrepreneurial intention, Dentist career, Public hospitals in china

\footnotetext{
*Correspondence: jhuzhang@must.edu.mo

${ }^{1}$ School of Business, Macau University of Science and Technology,

Avenida Wai Long, Taipa, Macao S.A.R., China

Full list of author information is available at the end of the article
}

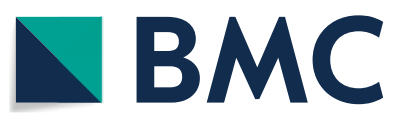

(c) The Author(s) 2020. Open Access This article is licensed under a Creative Commons Attribution 4.0 International License, which permits use, sharing, adaptation, distribution and reproduction in any medium or format, as long as you give appropriate credit to the original author(s) and the source, provide a link to the Creative Commons licence, and indicate if changes were made. The images or other third party material in this article are included in the article's Creative Commons licence, unless indicated otherwise in a credit line to the material. If material is not included in the article's Creative Commons licence and your intended use is not permitted by statutory regulation or exceeds the permitted use, you will need to obtain permission directly from the copyright holder. To view a copy of this licence, visit http://creativecommons.org/licenses/by/4.0/. The Creative Commons Public Domain Dedication waiver (http://creativeco mmons.org/publicdomain/zero/1.0/) applies to the data made available in this article, unless otherwise stated in a credit line to the data. 


\section{Background}

\section{Dentists' entrepreneurial activities and intention}

Dentists traditionally have a higher level of entrepreneurship, or are more likely than other healthcare professionals (such as physicians, surgeons or nurses), to start up their own practice, or move into private practice $[1,2]$. Entrepreneurship refers to the ability to identify new opportunities, the possession of executive skills to obtain resources and implement plans, as well as leadership skills, including risk attitude and tolerance [3, 4]. Specifically, the concept of entrepreneurship in dentistry involves initiating or developing a dental practice or relevant business, organizing the necessary financial and human resources, and taking the associated risks and rewards [4]. Dentists may also be engaged in the manufacturing of dental instruments, equipment or materials. During the past decades, as results of healthcare reforms worldwide, market factors (such as service competition and patient satisfaction) are playing an increasingly important role in the operation environment of dentistry. Promoting the entrepreneurship of dentists has increasingly received attention in both dentistry and dental education worldwide $[1,4,5]$. To achieve this goal effectively, it is necessary to have an in-depth understanding of dentist' entrepreneurial intention (EI) and related influential factors.

Entrepreneurial intention (EI) is defined as "the conscious state of mind that precedes action and directs attention toward entrepreneurial behaviors such as starting a new business and becoming an entrepreneur" [6, 7]. As the first stage of a series of actions in organizational founding, EI is an important part of the business planning process $[8,9]$, reflecting an individual's readiness to engage in subsequent entrepreneurial activities [10-14]. It may also be influenced by factors, such as an entrepreneur's demographic, professional knowledge, technical skills, entrepreneurial behaviors [15], as well as psychological characteristics [16, 17]. Employees in knowledgeintensive industries may demonstrate entrepreneurial intention and behaviors with some unique features [1618]. For example, in general, business entrepreneurs are more likely to be active with start-up and innovations in their 20s [19-21], whereas dentists' optimal time for starting a private practice may be postponed due to education and professional qualification requirements. Other factors, such as a family business background or the social-cultural environment, may also influence an individual's EI through the channels of social skills development, confidence and business values [22, 23].

\section{The demand and supply of dental care service in China}

Due to traditional ignorance about oral health and past social-economic reasons, the general oral health status of Chinese residents is a serious concern and there has been a rapid growth in demand for dental service [24]. In 2017, the caries incidence of the population was greater than $50 \%$, and less than $50 \%$ of the residents had a healthy periodontal condition [25]. The caries incidence for children at age of 5 years was $70.9 \%$, and $34.5 \%$ at the age of 12 years [25]. For adults between the age of 35 and 44 years, the dental cavity detection frequency was $96.7 \%$ and the gingival bleeding detection frequency was $87.4 \%$ [25]. With the significantly enhanced awareness of preventive dental health and improved living standards in China during the past decade, public demand for dental care surged quickly with an annual growth rate of about $11 \%$ [26]. In 2020, China's dental care market was estimated to be worth RMB100 billion (US\$14 billion) [26].

The current social health insurance scheme in China only covers minimum basic treatment-oriented dental services and does not include prevention-oriented dental care services, dental crowns with advanced materials, orthodontics or dental implants [24]. It is estimated that over $85 \%$ of the dental costs have to be paid out of pocket [24]. Many urban middle-class residents, especially those in central cities, prefer to choose private dental clinics because they are willing to and can afford to pay for the better patient experience provided by private dental clinics $[27,28]$. These private clinics can provide a facility with a patient-friendly environment, patient communications with patients, advanced diagnostic and treatment equipment, a short or no waiting time, flexibility in appointments, and so on [26, 29, 30].

At the current stage, the dental care supply in China is still insufficient to meet the rising demand. By 2018, there were 314,347 trained dentistry personnel in mainland China, among whom 171,587 (54.6\%) were dentists, $37.8 \%$ were dental nurses and $7.6 \%$ were dental technicians. The density of dentistry personnel (per 1000 population) was about 0.129 in 2018 , while the WHO standard is 0.2 [31]. There were in total 75,399 dental service units among all healthcare providers in mainland China [31]. By institution number, $73.8 \%$ of these service units exist as dental departments of general hospitals [24].

To improve the supply of dental health care, over the past five years there has been some policy reforms in China, such as multi-sited practicing by qualified dentists and a simplified process of private clinic license application and approval. Significantly, there are favorable policies encouraging private venture capital to enter the dentistry field in China [24, 32]. Due to these reasons, investment capital has actively flowed into the private dental sector and some large oral-care companies have tried to establish chain clinics through the acquisition of existing stand-along clinics, especially those owned and operated by qualified dentists (for example, dentists who 
graduated from leading dental schools or who are working in top public hospitals in the region) $[26,29,33]$. The rapid growth of the private dental care market in China has created a high demand for qualified dentists with entrepreneurship from public hospitals, where most dentists practice and develop in their sophistication of practice [26]. While a career in public hospitals may provide job security and a decent professional reputation, private practice and dental entrepreneurs have the advantages of a more attractive income and the potential of a lucrative financial return from a successful dental venture business.

As employees in a knowledge-intensive industry, dentists' entrepreneurial activities may have some unique features and associated factors. However, currently there is only a very small volume of literature studying this aspect of dentists [5, 34, 35]. Some studies focused on dental students [36-40], but they are not yet perfectly comparable to dentists in their actual career path with various social-economic responsibilities. The recent rapid growth of private dentistry in China and the high demand for dentists in public hospitals has provided a good research opportunity.

\section{Study location}

This study focuses on the dentists in public hospitals in five major cities of Guangdong Province (Guangzhou, Shenzhen, Foshan, Zhuhai, and Zhongshan). Located in the Pearl River Delta Area in Guangdong province, Guangzhou and Shenzhen are among the top megacities of China and the studied cities are among the most economically developed areas in China with a high level of personal income. Since the private economy (especially small to medium enterprises) developed early in Guangdong across all industries, including healthcare, residents in this area accept private dental care that meets their quality and personal experience preference [26]. In industrial cities in Guangdong, such as Shenzhen, with limited public medical resources and a strong individual capacity to pay, the private dental sector has very large potential market growth opportunity [26].

In 2018 , there were 20,681 certified dentistry personnel in Guangdong province [41]. The density of dentistry personnel (per 1000 population) was about 0.18 , whereas the national average level was 0.129 . There are in total 172 general public hospitals and specialized dental hospitals in Guangdong Province. There are 104 hospitals (60\%) located in the 5 major cities selected in this study while the remaining 17 cities in total have 68 hospitals (40\%) [41]. Specifically, 53 hospitals (30\%) are located in Guangzhou City (the capital of Guangdong Province), 21 (12\%) in Foshan, 17 (10\%) in Shenzhen, 8 (5\%) in Zhuhai and 5 (3\%) in Zhongshan [26].

\section{Aim of this study}

This study aims to examine the entrepreneurial intentions of dentists in the public hospitals in major cities of Guangdong Province, China, and the associated key factors, including educational background, professional qualification, years of practice, their entrepreneurial or leadership skills, family background, as well as risk aversion level.

\section{Methods \\ Ethics approval and consent to participate}

Ethical approval of this study was obtained from the Research Ethics Committee at the School of Business, Macau University of Science and Technology (No: MUST/MSB/D/19/0128). The verbal informed consent procedure was approved by the Research Ethics Committee. The questionnaire has a brief cover letter in written form, describing the research purpose of the collected information and the confidential guarantee policy. Before starting the questionnaire, the ethics statement was disclosed to all respondents and verbal informed consents were obtained from all respondents. All responses were voluntary and anonymous.

\section{Questionnaire}

The questionnaire adopted an established scale to measure the key concepts of entrepreneurial intention and behaviors [42] and was pre-tested for validity by collegiate faculty, dentists, and dental students randomly selected from major public hospitals in Guangzhou, China. The reliability of the scales was estimated to be 0.81 . (See Additional file 1 for the full version of the questionnaire.)

\section{Sampling}

A Snowball sampling method was adopted. Two or three senior dentists in the major public hospitals in each city were first randomly sampled, then each of them gave multiple referrals to other qualified dentists in their cities. This pattern was repeated until a sufficient number of dentists became available for the sample. The number of dentist respondents is proportional to the dental healthcare workforce population in each city $[26,41]$. About $51 \%$ of the respondents in this sample are from Guangzhou, 20\% from Foshan, 16\% from Shenzhen, 8\% from Zhuhai and 5\% from Zhongshan.

The sampling and survey process was performed during the ten months between September 2018 and June 2019. A total of 400 questionnaires were distributed in either paper or electronic forms through WeChat (the dominant social media App in China), depending on the respondents' preference and convenience. Eventually, 
336 valid responses were received (effective return rate $=84 \%$ ), equivalent to about $3.6 \%$ of the total registered dentist population in the studied area. All questionnaires were self-administrated. All data collected through the questionnaires were entered and coded.

\section{Statistical methods}

\section{Dependent variable}

EI is a useful and practical approach to understanding actual entrepreneurial behavior. This survey of dentists' EI captures their objective orientation, such as plans, wishes and preference for engaging in entrepreneurial dental business activities [43].

It was measured by one single question adapted from Krueger et al. [44], "It is likely that I will start and run my business in dentistry in the near future." Responses were measured with a 5-point Likert scale, with 1 being least likely and 5 being most likely. For logistic regression analysis, a dummy variable of EI was then created according to the number values of the answers. EI was assigned with the value of " 1 " if answers were " $5=$ most likely", or " $4=$ likely". EI took the value of " 0 " for other answers $(3=$ neutral, $2=$ unlikely, $1=$ very unlikely $)$.

\section{Independent variables}

This study hence includes these relevant factors accordingly.

\section{Demographic and professional characteristics}

This part contains questions about gender, age, educational level, professional qualification and years of practice. The hospital workplace was measured in terms of employee numbers, rather than bed numbers, because most dental treatment is performed with outpatients, rather than inpatients.

\section{Entrepreneurial behavior}

This variable reflects personalities and skills associated with identifying and exploring business opportunities, taking risks and being engaged in implementation of business plans [15]. The scale for measuring entrepreneurial behaviors in this study was adopted from Afsar et al. [42], that is especially designed for employee's entrepreneurial behavior in knowledge-intensive industries [16-18]. Accordingly, the level of a dentist's entrepreneurial behavior is the average score of six dimensions. (1) "Encourage team members to take the initiative with their own ideas."; (2) "Inspire team members to think about their work in innovative perspectives"; (3) "Devote time to help team members improve the products and services"; (4) "Vividly describe how things could be in the future and what is needed to reach the goal"; (5) "Effectively organize team to meet a challenge"; (6)
"Create an environment where people get excited about making improvement". All measurements are based on a 5 -point Likert scale from 1 (disagree strongly) to 5 (agree strongly).

\section{Risk aversion}

An individual's risk-taking attitude may have a direct and significant effect on EI [45]. Strong perceptions regarding the potential loss of business, would lead to a lower level of EI [46]. Risk aversion in this study was measured by the established tool developed by Barbosa et al.[47]. Presented with the statement, "The failure of starting a private business will have a negative impact on my future career.", respondents were asked to rate how closely this statement reflected their perceptions and responses using a 5-point Likert scale from 1 (disagree strongly) to 5 (agree strongly).

\section{Entrepreneurial family background}

Family background and parental role models can affect EI through attitudes [48, 49], innovation, and creative capacities [50,51]. There is a question asked about whether or not a respondent had family/relative members who engaged in entrepreneurship.

\section{Statistical analysis}

The baseline model was a multivariate logistic regression model analyzing the major factors associated with the dependent variable, the dentists' EI, that is a dummy variable, taking the value of " 1 " if answering "having entrepreneurial intention". The independent variables included basic demographic and professional characteristics of the dentists.

The full model added additional variables to capture potential influences from the dentist's personality, personal skills and resources, such as 'entrepreneurial behavior', 'risk aversion' and 'entrepreneurial family background.' All statistical analyses were performed with STATA (version 15).

\section{Results}

Table 1 reports the demographic and professional characteristics of the sample. The result showed that $35.71 \%$ of the dentist respondents have EI. About $70.83 \%$ of the respondents were female. More than three fourths of the respondents were less than 35 years old and only $11.01 \%$ were aged 46 years or more. As for educational level, nearly half of the dentists only have an associate or bachelor's degree and only $10.71 \%$ of them have a doctoral degree. The respondents in the sample hold various professional positions and work experience groups are well represented. Among all public hospitals in this sample, $72.02 \%$ of them are the major ones with 
Table 1 Demographic and professional characteristics of the respondents $(\mathrm{N}=336)$

\begin{tabular}{|c|c|}
\hline Variables & $\mathrm{N}(\%)$ \\
\hline \multicolumn{2}{|l|}{ Entrepreneurial intention } \\
\hline Yes & $120(35.71)$ \\
\hline No & $216(64.29)$ \\
\hline \multicolumn{2}{|l|}{ Gender } \\
\hline Male & $98(29.17)$ \\
\hline Female & $238(70.83)$ \\
\hline \multicolumn{2}{|l|}{ Age (years) } \\
\hline $20-25$ & $80(23.81)$ \\
\hline $26-35$ & $170(50.6)$ \\
\hline $36-45$ & 49 (14.58) \\
\hline $46-60$ & $37(11.01)$ \\
\hline \multicolumn{2}{|l|}{ Educational level } \\
\hline Associate degree & $73(21.73)$ \\
\hline Bachelor's degree & $94(27.98)$ \\
\hline Master's degree & $133(39.58)$ \\
\hline Doctoral degree & $36(10.71)$ \\
\hline \multicolumn{2}{|l|}{ Years of practice } \\
\hline 1 or less & $116(34.52)$ \\
\hline $2-5$ & $102(30.36)$ \\
\hline $6-10$ & $41(12.2)$ \\
\hline 11 or more & $77(22.92)$ \\
\hline \multicolumn{2}{|l|}{ Professional qualification } \\
\hline Intern & $83(24.7)$ \\
\hline Resident & $101(30.06)$ \\
\hline Attending dentist & $63(18.75)$ \\
\hline Associate/chief dentists & $39(11.61)$ \\
\hline Administration & $50(14.88)$ \\
\hline \multicolumn{2}{|c|}{ Number of employees at workplace hospital } \\
\hline 50 or less & $41(12.20)$ \\
\hline $51-100$ & $31(9.23)$ \\
\hline $101-200$ & $22(6.55)$ \\
\hline 201 or more & $242(72.02)$ \\
\hline \multicolumn{2}{|c|}{ Entrepreneurial family member } \\
\hline Yes & $262(77.98)$ \\
\hline No & $74(22.02)$ \\
\hline
\end{tabular}

more than 200 employees. About $78 \%$ of the respondents reported to have family members or relatives running or owning dental clinics.

Table 2 reports details of the survey questions and descriptive statistics about dentists' risk aversion and entrepreneurial behavior. The average score of risk perception is 3.14 , indicating that the dentists were slightly risk averse. While the mean of the dentists' entrepreneurial behavior score is 3.62 , indicating a moderately active level.
Table 3 analyzes the characteristics of the respondents with or without EI respectively. Male dentists were more likely to report having EI. There were no statistically significant differences among various groups of age, educational level, and years of practice. Dentists in large hospitals (with more than 200 employees) are less likely to report having EI, while those in small hospitals (with less than 50 employees) are most likely to report having EI. Additionally, dentists who have entrepreneurial family members were significantly more likely to report having EI. Meanwhile, dentists with a high level of risk aversion are significantly less likely to report having EI.

Analysis results of the full model are reported in Table 4, using a multivariable logistic regression model. The odds ratio for females is $0.365(p=0.001)$, indicating that the probability of a female dentist reporting planning to enter the private sector (EI) on average is only about $36.5 \%$ as likely as a male respondent. The EI of dentists in the age group of 36-45 years and 46-60 years were about 14 times $(p=0.012)$ and 8.45 times $(p=0.066)$ respectively as likely as those in the age group of 20-25 years.

Respondents with a higher Educational level are less likely to report EI, especially dentists with masters $(\mathrm{OR}=0.221, p=0.021)$ or doctoral degrees $(\mathrm{OR}=0.118$, $p=0.005)$. Regarding the professional qualification status of respondents, an attending dentist $(\mathrm{OR}=7.812, p=0.016)$ and associate/chief dentists (OR=9.857, $p=0.021)$ have significantly much higher odds of reporting EI. Dentists in administration positions are not significantly more likely to report EI.

Meanwhile, years of practice are negatively associated with the EI. The odds ratios for dentists with 6-10 years and those with 11-years of work experience are 0.133 $(p=0.014)$ and $0.015(p<0.0001)$ respectively. The results suggest that dentists from mid-large hospitals (with 101200 employees) $(\mathrm{OR}=3.554, p=0.036)$ and small public hospitals (with less than 50 employees) $(\mathrm{OR}=2.398$, $p=0.044)$ are on average significantly more likely than those in large hospitals (more than 200 employees) to report stronger EI, whereas the difference among those in medium-size hospitals (with 51-100 employees) are insignificant.

As reported in the bottom lines of Table 4, dentists with a higher level of entrepreneurial behaviors $(O R=3.602$, $\mathrm{p}<0.0001$ ), or with an entrepreneur family member $(\mathrm{OR}=3.672, p=0.003)$, are significantly more likely to report EI. However, dentists with stronger risk aversion are less likely to report $\mathrm{EI}(\mathrm{OR}=0.702, p=0.007)$. 
Table 2 Descriptive statistics of dentists' risk aversion and entrepreneurial behaviors $(\mathrm{N}=336)$

\begin{tabular}{|c|c|c|c|c|c|}
\hline \multirow{2}{*}{$\begin{array}{l}\text { Risk aversion } \\
\text { Entrepreneurial behavior score* }\end{array}$} & \multicolumn{3}{|c|}{3.14 (mean) } & & 1.04 (s.d.) \\
\hline & \multicolumn{3}{|c|}{3.62 (mean) } & & 0.67 (s.d.) \\
\hline \multicolumn{6}{|l|}{ Risk aversion } \\
\hline $\begin{array}{l}\text { Strongly Disagree } \\
\text { (1) }\end{array}$ & $\begin{array}{l}\text { Disagree } \\
\text { (2) }\end{array}$ & $\begin{array}{l}\text { Undecided } \\
\text { (3) }\end{array}$ & $\begin{array}{l}\text { Agree } \\
\text { (4) }\end{array}$ & $\begin{array}{l}\text { Strongly Agree } \\
\text { (5) }\end{array}$ & $P$ value** \\
\hline \multicolumn{6}{|c|}{ Q 1. The failure of starting a private business will have a negative impact on my future career. [N (\%)] } \\
\hline $16(4.76)$ & $87(25.89)$ & $100(29.76)$ & $100(29.76)$ & $33(9.82)$ & $<0.01$ \\
\hline \multicolumn{6}{|l|}{ Entrepreneurial behavior } \\
\hline $\begin{array}{l}\text { Strongly Disagree } \\
\text { (1) }\end{array}$ & $\begin{array}{l}\text { Disagree } \\
\text { (2) }\end{array}$ & $\begin{array}{l}\text { Undecided } \\
\text { (3) }\end{array}$ & $\begin{array}{l}\text { Agree } \\
\text { (4) }\end{array}$ & $\begin{array}{l}\text { Strongly Agree } \\
\text { (5) }\end{array}$ & $P$ value* \\
\hline \multicolumn{6}{|c|}{ Q 1. This employee encourages others to take the initiative for their own ideas. [N (\%)] } \\
\hline $1(0.3)$ & $6(1.79)$ & $70(20.83)$ & $203(60.42)$ & $56(16.67)$ & $<0.01$ \\
\hline \multicolumn{6}{|c|}{ Q 2. This employee inspires others to think about their work in new and stimulating ways. [N (\%)] } \\
\hline $3(0.89)$ & $12(3.57)$ & $84(25)$ & $171(50.89)$ & $66(19.64)$ & $<0.01$ \\
\hline \multicolumn{6}{|c|}{ Q 3. This employee devotes time to helping others find ways to improve our products and services. [N (\%)] } \\
\hline $5(1.49)$ & $21(6.25)$ & $114(33.93)$ & $155(46.13)$ & $41(12.2)$ & $<0.01$ \\
\hline \multicolumn{6}{|c|}{ Q 4. This employee vividly describes how things could be in the future and what is needed to get us there. [N (\%)] } \\
\hline $9(2.68)$ & $43(12.8)$ & $151(44.94)$ & $112(33.33)$ & $21(6.25)$ & $<0.01$ \\
\hline \multicolumn{6}{|c|}{ Q5. This employee gets people to rally together to meet a challenge. [N (\%)] } \\
\hline $7(2.08)$ & $27(8.04)$ & $124(36.9)$ & $146(43.45)$ & $32(9.52)$ & $<0.01$ \\
\hline \multicolumn{6}{|c|}{ Q 6. This employee creates an environment where people get excited about making improvements. [N (\%)] } \\
\hline $9(2.68)$ & $21(6.25)$ & $109(32.44)$ & $165(49.11)$ & $32(9.52)$ & $<0.01$ \\
\hline
\end{tabular}

*The sample average score of Q1 to Q6

**Chi-squared test

\section{Discussion}

As for the association between EI and demographic characteristics, the findings in this study are generally consistent with existing literature, but with some exceptions due to the knowledge-intensive feature of dentistry.

Female dentists in this study are found on average to be less likely than males to report having EI. This finding is consistent with existing literature [52-54]. The driving forces and pathways behind the gender difference are complicated [53] and may be due to various factors, such as social/cultural gender roles $[55,56]$, natural differences in personality and family responsibilities $[57,58]$.

The findings in the study indicate that age is a key factor with a strong association with dentists' EI, and with the strongest effects among the group of 36-45 years old and remaining strong among the upper middle age group. Unlike general business startups with active innovations by the young generations [19-21], the professional qualification or criteria required by dentistry can only be obtained after years of education, practice, and experience.

A wide range of literature reports that education helps to increase EI through developing the natural entrepreneurial tendencies and enhancing the managerial ability of individuals [59]. However, this study finds that dentists in China with postgraduate education are much less likely to report having EI, when other potential determinant factors are controlled. This may be due to the fact that, during the past decades, dental education in China has been focusing on either the research and academic career, or a career path in prestigious hospitals, with no or very little entrepreneurial knowledge and training provided. Additionally, dentists with long years of postgraduate dental education have a greater opportunity cost for their career and social reputation if they take risks to engage in entrepreneurship [60].

A dentist's professional qualification is another key factor with a strong positive association for EI. This finding can be explained by the fact that dentistry highly values professional qualification, which is especially necessary for the private sector if they want to obtain accreditation or to attract patients $[61,62]$.

The findings in this study indicate that years of practice are negatively associated with EI among dentists in China, holding other factors constant. Given a small group of literature reporting the decline in selfemployment among near-retirees [63], most literature studying general business reports positive associations 
Table 3 Associations between dentists' entrepreneurial intention and relevant factors $(\mathrm{N}=336)$

\begin{tabular}{|c|c|c|c|}
\hline & $\begin{array}{l}\text { Have Entrepreneurial intention } \\
(N=120) \\
\mathrm{N}(\%)\end{array}$ & $\begin{array}{l}\text { Do not have Entrepreneurial } \\
\text { intention } \\
(N=216) \\
N(\%)\end{array}$ & $P$ value \\
\hline \multicolumn{4}{|l|}{ Gender } \\
\hline Male & $58(59.18 \%)$ & $40(40.82 \%)$ & \multirow[t]{2}{*}{$<0.0001$} \\
\hline Female & $62(26.05 \%)$ & $176(73.95 \%)$ & \\
\hline \multicolumn{4}{|l|}{ Age (years) } \\
\hline $20-25$ & 30 (37.5\%) & $50(62.5 \%)$ & \multirow[t]{4}{*}{0.631} \\
\hline $26-35$ & $57(33.53 \%)$ & $113(66.47 \%)$ & \\
\hline $36-45$ & $21(42.86 \%)$ & $28(57.14 \%)$ & \\
\hline $46-60$ & $12(32.43 \%)$ & $25(67.57 \%)$ & \\
\hline \multicolumn{4}{|l|}{ Educational level } \\
\hline Associate degree & $28(38.36 \%)$ & $45(61.64 \%)$ & \multirow[t]{4}{*}{0.932} \\
\hline Bachelor's degree & $34(36.17 \%)$ & $60(63.83 \%)$ & \\
\hline Master's degree & $45(33.83 \%)$ & $88(66.17 \%)$ & \\
\hline Doctoral degree & $13(36.11 \%)$ & $23(63.89 \%)$ & \\
\hline \multicolumn{4}{|l|}{ Professional qualification } \\
\hline Intern & $31(37.35 \%)$ & $52(62.65 \%)$ & \multirow[t]{5}{*}{0.065} \\
\hline Resident & $32(31.68 \%)$ & $69(68.32 \%)$ & \\
\hline Attending dentist & $28(44.44 \%)$ & $35(55.56 \%)$ & \\
\hline Associate/chief dentists & $18(46.15 \%)$ & $21(53.85 \%)$ & \\
\hline Administration & $11(22.00 \%)$ & $39(78.00 \%)$ & \\
\hline \multicolumn{4}{|l|}{ Years of practice } \\
\hline 1 or less & $45(38.79 \%)$ & $71(61.21 \%)$ & \multirow[t]{4}{*}{0.588} \\
\hline $2-5$ & $33(32.35 \%)$ & $69(67.65 \%)$ & \\
\hline $6-10$ & $17(41.46 \%)$ & $24(58.54 \%)$ & \\
\hline 11 or more & $25(32.47 \%)$ & $52(67.53 \%)$ & \\
\hline \multicolumn{4}{|c|}{ Number of employees at workplace hospital } \\
\hline 50 or less & $22(53.66 \%)$ & $19(46.34 \%)$ & \multirow[t]{4}{*}{0.041} \\
\hline $51-100$ & $9(29.03 \%)$ & $22(70.97 \%)$ & \\
\hline $101-200$ & $10(45.45 \%)$ & $12(54.55 \%)$ & \\
\hline 201 or more & $79(32.64 \%)$ & $163(67.36 \%)$ & \\
\hline \multicolumn{4}{|l|}{ Risk aversion level } \\
\hline 1 (very low) & $9(56.25)$ & $7(43.75)$ & \multirow[t]{5}{*}{$<0.0001$} \\
\hline 2 (low) & $42(48.28)$ & $45(51.72)$ & \\
\hline 3 (neutral) & $31(31)$ & $69(69)$ & \\
\hline 4 (high) & $31(31)$ & $69(69)$ & \\
\hline 5 (very high) & $7(21.21)$ & $26(78.79)$ & \\
\hline \multicolumn{4}{|c|}{ Entrepreneurial family member } \\
\hline Yes & $108(41.22 \%)$ & $154(58.78 \%)$ & \multirow[t]{2}{*}{$<0.0001$} \\
\hline No & $12(16.22 \%)$ & $62(83.78 \%)$ & \\
\hline
\end{tabular}

* Chi-squared test

between working experience and EI [64-66]. Actually, the findings in this study have reasonably reflected the professional feature of dentistry. First, without the sufficient professional qualification for dentistry, years of practice alone does not bring a career advantage in private sector practice. Second, the positive effects of entrepreneurial knowledge acquired through work experience have largely been reflected in the regression analysis by the variable of professional qualifications for dentists. In China, some senior-aged dentists received only a two-year college level education in the late 1980 's and currently can only attain a relatively low 
Table 4 Multivariate logistic regression analysis of Dentists' entrepreneurial intention and associated factors (Full model, with personality variables) $(\mathrm{N}=336)$

\begin{tabular}{|c|c|c|}
\hline & Odds ratio $(95 \% \mathrm{Cl})$ & $P$ value \\
\hline \multicolumn{3}{|l|}{ Gender } \\
\hline Male & 1 & \\
\hline Female & $0.365(0.197-0.676)$ & 0.001 \\
\hline \multicolumn{3}{|l|}{ Age (years) } \\
\hline $20-25$ & 1 & \\
\hline $26-35$ & $2.915(0.81-10.487)$ & 0.101 \\
\hline $36-45$ & $14.205(1.804-111.871)$ & 0.012 \\
\hline $46-60$ & $8.45(0.868-82.254)$ & 0.066 \\
\hline \multicolumn{3}{|l|}{ Educational level } \\
\hline Associate degree & 1 & \\
\hline Bachelor's degree & $0.36(0.111-1.169)$ & 0.089 \\
\hline Master's degree & $0.221(0.061-0.798)$ & 0.021 \\
\hline Doctoral degree & $0.118(0.026-0.531)$ & 0.005 \\
\hline \multicolumn{3}{|l|}{ Professional qualification } \\
\hline Intern & 1 & \\
\hline Resident & $1.654(0.52-5.264)$ & 0.394 \\
\hline Attending dentist & $7.812(1.471-41.475)$ & 0.016 \\
\hline Associate/chief dentists & $9.857(1.411-68.848)$ & 0.021 \\
\hline Administration & $0.827(0.206-3.318)$ & 0.789 \\
\hline \multicolumn{3}{|l|}{ Years of practice } \\
\hline 1 or less & 1 & \\
\hline $2-5$ & $0.389(0.154-0.982)$ & 0.046 \\
\hline $6-10$ & $0.133(0.027-0.664)$ & 0.014 \\
\hline 11 or more & $0.015(0.002-0.143)$ & $<0.0001$ \\
\hline \multicolumn{3}{|c|}{ Number of employees at workplace hospital } \\
\hline 201 or more & 1 & \\
\hline $101-200$ & $3.554(1.09-11.588)$ & 0.036 \\
\hline $51-100$ & $1.163(0.426-3.179)$ & 0.768 \\
\hline 50 or less & $2.398(1.025-5.611)$ & 0.044 \\
\hline Entrepreneurial behavior & $3.602(2.152-6.028)$ & $<0.0001$ \\
\hline Risk aversion & $0.702(0.542-0.909)$ & 0.007 \\
\hline Have entrepreneurial family member & $3.672(1.571-8.584)$ & 0.003 \\
\hline
\end{tabular}

level of professional qualification despite their many years of working.

The results in the full model in Table 4 indicate that dentists in mid-large hospitals (with 101-200 employees) and the small hospitals (with less than 50 employees) have a much higher level of EI. The overall professional satisfaction of a dentist's career in China is most associated with factors such as respect, delivery of care, income, and patient relations [67]. The large hospitals in China, those with top tertiary connections, are always regarded with strong respect and supported with various types of social and financial resources. Meanwhile, small hospitals are on the other side of the spectrum. Hence, the career opportunity costs of entrepreneurial activities for the dentists from small hospitals are lower than for those in large hospitals. Dentists in mid-large hospitals may have a strong educational background and high quality skills too, but hold less prestigious career positions compared to those in top large hospitals. Taking these factors together into consideration, they may have a strong EI to start private practice to promote their career.

This study found that dentists' entrepreneurial behavior levels had a significant positive association with their EI. These results are consistent with existing literature [35, 68]. Entrepreneurial behavior features actually reflect a person's personality traits that indicate the possibility of becoming a leader, traits such as being proactive and innovative, and strong teamwork 
skills [14]. This finding also suggested that dentists with strong leadership skills or management skills in the public hospitals of China have high probabilities to leave for their own entrepreneurial activities.

This study found highly significant negative association between risk aversion and EI among dentists in China's public hospitals. Risk aversion may indirectly reduce the possibility of EI through the channels of entrepreneurial skills and self-efficacy [60]. While dentists in China are more sophisticated and socially experienced than dental students studied [60], they actually may be even more risk-averse due to the larger social and economic opportunity cost in terms of career path, reputation and family economic responsibilities to be considered.

This study found a strong positive association between an individual's EI and their family members or relatives involvement in dentistry entrepreneurial activities. This result is consistent with literature $[22,23]$. Further, active involvement in a social network may help to identify and obtain various resources needed for a start-up [36, 69].

\section{Limitation}

This study is a cross sectional survey, hence it has the limitations inherent in this research method. First, there may be non-random sampling errors and measurement errors during the process of the survey. However, these errors are not major concerns in this study, because precautious actions and sampling process management were performed to minimize these errors, though this is no guarantee of complete elimination.

Second, this study is based on 336 observations of dentists in Guangdong Province of China, which is among the most developed area in China. Hence, caution is necessary when generalizing the findings to the national level.

Third, due to the survey research design using observatory data, this study may be subject to the survival bias. Dentists who are very good at entrepreneurial activities, or with strong skills may have left the public hospitals to start their private practice, and as a consequence, only those with low EI and skills remain working in the public hospitals. Hence, the analysis was limited to an associative relationship, rather than being interpreted as causal effects.

Forth, the analysis about EI may be subject to the omitted variable bias. There are actually various factors (e.g., personality characteristics and social/culture environment) affecting a person's EI and these factors may also have complicated interaction effects on each other. However, it is impossible to include all potential influential factors in the estimation model.

\section{Conclusions}

Analyzing the survey results of 336 dentists from public hospitals in five major cities in Guangdong Province (China), this study found that, within the knowledgeintensive industry of dentistry, dentists' entrepreneurial behaviors have their own features. Accumulation of practical skills during their career, as implied by age, professional qualifications and leadership skills, help to promote EI among dentists, whereas an academic oriented education degree per se does not promote EI. Postgraduate education and years of practice per se are not directly positively associated with a higher level of EI among dentists. The finding that dentists in mid-large and small hospitals in China are more likely to report EI is counter to the traditional perception, one that is biased toward the dentists in top large hospitals. Additionally, female dentists have a lower level of EI, suggesting more social supports or self-efficacy are necessary to promote female dentists' entrepreneurship and to help them to choose optimal career path.

\section{Supplementary information}

Supplementary information accompanies this paper at https://doi. org/10.1186/s12903-020-01331-z.

Additional file 1. Questionnaire for survey about the entrepreneurial intention of dentists in public hospitals in major cities in Guangdong (South China).

\section{Abbreviation}

El: Entrepreneurial intention.

\section{Acknowledgements}

The authors thank all the dentists who participated the survey for this study.

\section{Authors' contributions}

$\mathrm{BP}$ and $\mathrm{JHZ}$ conceptualized the study and designed the survey. BP performed the survey and collected data. JW and JHZ designed the statistical analysis method and performed the data analysis. BP, JW, HZ and JHZ reviewed literature, prepared, and edited the manuscript. All the authors have read and approved the final manuscript for publication.

\section{Funding}

This work was supported by the Macao Higher Education Fund, and the Specialized Subsidy Scheme for Macao Higher Education Institutions in the Area of Research in Humanities and Social Sciences (Grant no: 49/DCCT/ DSES/2019). The funders had no role in study design, data collection and analysis, decision to publish, or preparation of the manuscript.

\section{Availability of data and materials}

The datasets used and analyzed in the current study are available from the corresponding author upon request.

\section{Ethics approval and consent to participate}

Ethical approval of this study was obtained from the Research Ethics Committee at the School of Business, Macau University of Science and Technology (No: MUST/MSB/D/19/0128). The verbal informed consent procedure was approved by the Research Ethics Committee. Before starting the questionnaire, the research purpose of the collected information and the confidential guarantee policy were disclosed and verbal informed consents were obtained from all respondents. All responses were voluntary and anonymous. 


\section{Consent for publication \\ Not applicable.}

\section{Competing interests}

There are no competing financial, professional, or personal interests that might have influenced the performance or presentation of the work described in this manuscript.

\section{Author details}

${ }^{1}$ School of Business, Macau University of Science and Technology, Avenida Wai Long, Taipa, Macao S.A.R., China. ${ }^{2}$ Nokia Solutions and Networks System Technology (Beijing) Co., Ltd., No. 1, Wangjing East Road, Chaoyang District, Beijing 100101, China.

Received: 3 August 2020 Accepted: 16 November 2020 Published online: 23 November 2020

\section{References}

1. Palaskar JN. Entrepreneurship in dentistry. J Dent Allied Sci. 2014;3(2):69.

2. Cumming DJ, Fischer E. Publicly funded business advisory services and entrepreneurial outcomes. Res Policy. 2012;41(2):467-81.

3. Dacin PA, Dacin MT, Matear M. Social entrepreneurship: why we don't need a new theory and how we move forward from here. Acad Manag Perspect. 2010;24(3):37-57.

4. Willcocks S. The entrepreneurial role in primary care dentistry. Br Dent J. 2012;212(5):213-7.

5. Sharma A, Jain M, Yadav N, Chahar P. Need for entrepreneurship education in undergraduate dental curriculum. Bus Strategy Environ. 2017:26(4):521-35.

6. Moriano JA, Gorgievski M, Laguna M, Stephan U, Zarafshani K. A crosscultural approach to understanding entrepreneurial intention. J Career Dev. 2012;39(2):162-85.

7. Esfandiar K, Sharifi-Tehrani M, Pratt S, Altinay L. Understanding entrepreneurial intentions: a developed integrated structural model approach. J Bus Res. 2019;94:172-82.

8. Ajzen I. The theory of planned behavior. Organ Behav Hum Decis Process. 1991;50(2):179-211.

9. Zampetakis LA, Gotsi M, Andriopoulos C, Moustakis V. Creativity and entrepreneurial intention in young people: empirical insights from business school students. Int J Entrep Innov. 2011;12(3):189-99.

10. Uddin MR, Bose TK. Determinants of entrepreneurial intention of business students in Bangladesh. Int J Bus Manag. 2012;7(24):128.

11. Bird B. Implementing entrepreneurial ideas: the case for intention. Acad Manag Rev. 1988;13(3):442-53.

12. Fishbein M, Ajzen I. Belief, attitude, intention, and behavior: An introduction to theory and research. 1977.

13. Abbey A. Cross-cultural comparison of the motivation for entrepreneurship. J Bus Entrep. 2002;14(1):69.

14. Kautonen T, Van Gelderen M, Fink M. Robustness of the theory of planned behavior in predicting entrepreneurial intentions and actions. Entrep Theory Pract. 2015;39(3):655-74.

15. De Jong JP, Den Hartog DN. How leaders influence employees' innovative behaviour. Eur J Innov Manag. 2007;10:41-64.

16. Farrukh M, Lee JWC, Shahzad IA. Intrapreneurial behavior in higher education institutes of Pakistan. J Appl Res High Educ. 2019;11:273-94.

17. Berraies S, Bchini B. Effect of leadership styles on financial performance: mediating roles of exploitative and exploratory innovations case of knowledge-intensive firms. Int J Innov Manag. 2019;23(03):1950020

18. Javed B, Abdullah I, Zaffar MA, ul Haque A, Rubab U. Inclusive leadership and innovative work behavior: the role of psychological empowerment. J Manag Organ. 2019;25(4):554-71.

19. Levesque $M$, Minniti $M$. The effect of aging on entrepreneurial behavior. J Bus Ventur. 2006;21(2):177-94.

20. Reynolds PD, Curtin RT. New firm creation in the United States. Berlin: Springer; 2007.

21. Boyd RL. Black and Asian self-employment in large metropolitan areas: a comparative analysis. Soc Probl. 1990;37(2):258-74.
22. Reynolds PD, Curtin RT. New firm creation in the United States. New York: Springer; 2009.

23. Altinay L. The relationship between an entrepreneur's culture and the entrepreneurial behaviour of the firm. J Small Bus Enterp Dev. 2008;15(1):111-29.

24. Zhou X, Xu X, Li J, Hu D, Hu T, Yin W, Fan Y, Zhang X. Oral health in China: from vision to action. Int J Oral Sci. 2018;10(1):1-6.

25. The National Committee for Oral Health. The fourth national epidemiological survey of oral health. Beijing: People's Medical Publishing House; 2018

26. KPMG. Commercial opportunities in the dental care market in China. KPMG Advisory (China) Limited. 2016. https://assets.kpmg/content/ $\mathrm{dam} / \mathrm{kpmg} / \mathrm{cn} / \mathrm{pdf} / \mathrm{en} / 2016 / 10 / \mathrm{commercial}$-opportunities-in-thedental-care-market-in-china.pdf. Accessed 29 Apr 2020.

27. Li C, Yao N, Yin A. Disparities in dental healthcare utilization in China. Community Dent Oral Epidemiol. 2018;46(6):576-85.

28. Qu X, Qi X, Wu B. Disparities in dental service utilization among adults in Chinese Megacities: do health insurance and city of residence matter? Int. J Environ Res Public Health. 2020;17(18):6851.

29. VBR Research. 2018 Dentistry White Paper. 2019. https://www.qianz han.com/analyst/detail/329/19010942cdbe03.html. Accessed 8 Oct 2020.

30. Nothhaft C. Medical care going private: BYBO. In: Made for China. Berlin: Springer; 2018. p. 139-47.

31. Sun $X Y$, Yuan $C$, Wang $X Z$, Wang $X$, Feng $X P$, Tai BJ, Hu Y, Lin HC, Wang $B$, Si $Y$. Report of the national investigation of resources for oral health in China. Chin J Dent Res. 2018;21(4):285-97.

32. Xu L, Zhang M. Regulated multi-sited practice for physicians in China: incentives and barriers. Glob Health J. 2018;2(1):14-31.

33. Forward-The Economist. 2018 The dental care market and development trend in China. 2019. https://www.qianzhan.com/analyst/detai l/220/190326ef0d8a0c.html. Accessed 8 Oct 2020.

34. Brijlal P, Brijlal P. Entrepreneurial knowledge and aspirations of dentistry students in South Africa: the influences of gender and race. Ind High Educ. 2013;27(5):389-98.

35. Mollica AG, Cain K, Callan RS. Using assessments of dental students' entrepreneurial self-efficacy to aid practice management education. J Dent Educ. 2017;81(6):726-31.

36. Nashleanas BM, McKernan SC, Kuthy RA, Qian F. Career influences among final year dental students who plan to enter private practice. BMC Oral Health. 2014;14(1):18

37. Halawany HS, Binassfour AS, AlHassan WK, Alhejaily RA, Al Maflehi N, Jacob V, Abraham NB. Dental specialty, career preferences and their influencing factors among final year dental students in Saudi Arabia. Saudi Dent J. 2017;29(1):15-23.

38. Fita S, Alshuraim F, Almulhim A, AlHumaid J, Alhareky M, Nazir M. Possible future career challenges and associated factors among dental students and interns. Int J Dentistry. 2020;2020:9730125.

39. Howell SE. Attitudes and behaviors regarding public health of dental school graduates from AT Still University. J Dent Educ. 2020;84:681-7.

40. Gordon S, Warren AC, Wright WG. Influence of community-based dental education on practice choice: preliminary data from East Carolina University. J Dent Educ. 2019;83(9):1000-11.

41. Commission CNH. China's health statistics yearbook. Beijing: Peking Union Medical College Press; 2019.

42. Afsar B, Badir YF, Saeed BB, Hafeez S. Transformational and transactional leadership and employee's entrepreneurial behavior in knowledgeintensive industries. Int J Human Resour Manag. 2017;28(2):307-32.

43. Krueger NF, Carsrud AL. Entrepreneurial intentions: applying the theory of planned behaviour. Entrep Reg Dev. 1993;5(4):315-30.

44. Krueger NF Jr, Reilly MD, Carsrud AL. Competing models of entrepreneurial intentions. J Bus Ventur. 2000;15(5-6):411-32.

45. Segal G, Borgia D, Schoenfeld J. The motivation to become an entrepreneur. Int J Entrep Behav Res. 2005;11:42-57.

46. Douglas EJ, Shepherd DA. Self-employment as a career choice: attitudes, entrepreneurial intentions, and utility maximization. Entrep Theory Pract. 2002;26(3):81-90.

47. Barbosa SD, Kickul J, Liao-Troth M. Development and validation of a multidimensional scale of entrepreneurial risk perception. Acad Manag Proc. 2007;2007(1):1-6. 
48. Krueger N. The impact of prior entrepreneurial exposure on perceptions of new venture feasibility and desirability. Entrep Theory Pract. 1993;18(1):5-21.

49. Delmar F, Davidsson P. Where do they come from? Prevalence and characteristics of nascent entrepreneurs. Entrep Reg Dev. 2000;12(1):1-23.

50. Mueller P. Entrepreneurship in the region: breeding ground for nascent entrepreneurs? Small Bus Econ. 2006:27(1):41-58.

51. McElwee G, Al-Riyami R. Women entrepreneurs in Oman: some barriers to success. Career Dev Int. 2003:8:339-46.

52. Santos FJ, Roomi MA, Liñán F. About gender differences and the social environment in the development of entrepreneurial intentions. J Small Bus Manag. 2016;54(1):49-66.

53. Nikou S, Brännback M, Carsrud Alan L, Brush CG. Entrepreneurial intentions and gender: pathways to start-up. Int J Gend Entrep. 2019;11(3):348-72.

54. Armuña C, Ramos S, Juan J, Feijóo C, Arenal A. From stand-up to start-up: exploring entrepreneurship competences and STEM women's intention. Int Entrep Manag J. 2020;16:69-92.

55. Moser CHMSB. Family background and gender: implications for interest in small firm ownership. Entrep Reg Dev. 1995;7(4):365-78.

56. Laguía A, García-Ael C, Wach D, Moriano JA. "Think entrepreneur-think male": a task and relationship scale to measure gender stereotypes in entrepreneurship. Int Entrep Manag J. 2019;15(3):749-72.

57. Fielden SL, Davidson MJ, Dawe AJ, Makin PJ. Factors inhibiting the economic growth of female owned small businesses in North West England. J Small Bus Enterp Dev. 2003;10:152-66.

58. Lee L, Wong PK, Der Foo M, Leung A. Entrepreneurial intentions: the influence of organizational and individual factors. J Bus Ventur. 2011;26(1):124-36.

59. Krasniqi BA. Personal, household and business environmental determinants of entrepreneurship. J Small Bus Enterp Dev. 2009;16:146-66.
60. Zhang P, Cain KW. Reassessing the link between risk aversion and entrepreneurial intention. Int J Entrep Behav Res. 2017;23:793-811.

61. Leggate M, Russell E. Attitudes and trends of primary care dentists to continuing professional development: a report from the Scottish dental practitioners survey 2000. Br Dent J. 2002;193(8):465-9.

62. Buck D, Newton T. Continuing professional development amongst dental practitioners in the United Kingdom: how far are we from lifelong learning targets? Eur J Dent Educ. 2002;6(1):36-9.

63. Heim BT. Understanding the decline in self-employment among individuals nearing retirement. Small Bus Econ. 2015;45(3):561-80.

64. Miralles F, Giones F, Riverola C. Evaluating the impact of prior experience in entrepreneurial intention. Int Entrep Manag J. 2016;12(3):791-813.

65. Yuan LW, Qalati SA, Iqbal S, Hussain RY, Ali S. Impact of Prior Work Experience on Entrepreneurial Intention and Theory of Planned Behaviour in the Context of Pakistan. J Entrep Organ Manag. 2019;8:268.

66. Kautonen T, Luoto S, Tornikoski ET. Influence of work history on entrepreneurial intentions in 'prime age'and 'third age': a preliminary study. Int Small Bus J. 2010;28(6):583-601.

67. Cui X, Dunning DG, An N. Satisfaction among early and mid-career dentists in a metropolitan dental hospital in China. J Healthc Leadersh. 2017;9:35.

68. Miralles F, Giones F, Gozun B. Does direct experience matter? Examining the consequences of current entrepreneurial behavior on entrepreneurial intention. Int Entrep Manag J. 2017;13(3):881-903.

69. Quan X. Prior experience, social network, and levels of entrepreneurial intentions. Manag Res Rev. 2012;35(10):945-57.

\section{Publisher's Note}

Springer Nature remains neutral with regard to jurisdictional claims in published maps and institutional affiliations.
Ready to submit your research? Choose BMC and benefit from:

- fast, convenient online submission

- thorough peer review by experienced researchers in your field

- rapid publication on acceptance

- support for research data, including large and complex data types

- gold Open Access which fosters wider collaboration and increased citations

- maximum visibility for your research: over 100M website views per year

At BMC, research is always in progress.

Learn more biomedcentral.com/submissions 